\title{
Analysis of the Penetration of English and American Literature in College English Teaching
}

\author{
Chen Ying \\ School of ForeignStudies,Xi an University,Xi'an,710065,China. \\ Chenying86223@163.com
}

\begin{abstract}
British and American literature is an important part of world literature. It not only shows the western unique artistic vision, but also shows the aesthetic value of the British and American culture. It is effective innovation of traditional teaching mode to put into college English teaching. It enriches not only the content in teaching, but also the students' spiritual world. It is conducive to establish health values and aesthetic view for students. This paper analyzes the necessity of British and American literature in college English teaching. And on this basis, I study the penetration methods in British and American literature.
\end{abstract}

Keywords-British and American literature; College English teaching; Necessity; Penetration methods

\section{INTRODUCTION}

Under the background of globalization, we should deepen the reform of teaching, improve the teaching quality, so as to adapt to the higher education in China and meet the needs of the national talent cultivation in the new period, English is not only a language basic course, but also a window that students can know western culture. British and American literature has important practical significance in English teaching.

\section{II. . INVESTIGATION AND ANALYSIS OF THE SITUATION OF COLLEGE ENGLISH TEACHING}

As one of the compulsory courses for English majors, British and American literature plays an important role in English learning. But for other students, they are still learning English course by listening, speaking, reading and writing. After thorough consideration, I decide to make a written survey. Participants were 90 first-year students of two classes in a university. Each class is a class of liberal arts and sciences, including 42 girls and 48 boys. I make a form first, then, let them fill in the forms in their spare time. I received 88 valid questionnaires. I arranged the statistics results through the excel software.The results are shown in Tab. 1.
TABLE I :STUDENT QUESTIONNAIRE

\begin{tabular}{|c|c|c|c|}
\hline \multicolumn{2}{|c|}{ Questions } & Results & $\begin{array}{l}\text { Perce } \\
\text { ntage }\end{array}$ \\
\hline \multicolumn{2}{|c|}{$\begin{array}{l}\text { Do you like British and } \\
\text { American literature? }\end{array}$} & Yes & $82 \%$ \\
\hline \multirow{3}{*}{\multicolumn{2}{|c|}{$\begin{array}{l}\text { What types of literary works } \\
\text { do you like? }\end{array}$}} & Novel & $75 \%$ \\
\hline & & Poetry & $19 \%$ \\
\hline & & Drama & $6 \%$ \\
\hline \multirow{2}{*}{\multicolumn{2}{|c|}{$\begin{array}{l}\text { What time do you like about } \\
\text { American and British } \\
\text { literature? }\end{array}$}} & Modern times & $90 \%$ \\
\hline & & Ancient times & $10 \%$ \\
\hline \multicolumn{2}{|c|}{$\begin{array}{l}\text { Do you want to understand } \\
\text { the British and American } \\
\text { writers' life and experience? }\end{array}$} & Yes & $95 \%$ \\
\hline \multirow{5}{*}{\multicolumn{2}{|c|}{$\begin{array}{l}\text { How do you know British } \\
\text { and American literature? }\end{array}$}} & The film and television & $76 \%$ \\
\hline & & Read the original texts & $20 \%$ \\
\hline & & Introduction from teacher & $14 \%$ \\
\hline & & $\begin{array}{l}\text { Newspapers, the magazine } \\
\text { and network }\end{array}$ & $23 \%$ \\
\hline & & Others & $9 \%$ \\
\hline \multirow{2}{*}{\multicolumn{2}{|c|}{$\begin{array}{l}\text { In what way do you want to } \\
\text { understand the British and } \\
\text { American literature in the } \\
\text { current situation? }\end{array}$}} & The film & $82 \%$ \\
\hline & & Introduction from teacher & $94 \%$ \\
\hline Reasons & \multicolumn{3}{|c|}{$\begin{array}{l}\text { They can understand the classic part of the works } \\
\text { quickly through the movies and teachers. Avoiding the } \\
\text { disadvantages of the esoteric English language. Thus, } \\
\text { they can understand the writers' experiences and works } \\
\text { in a very short period of time. }\end{array}$} \\
\hline
\end{tabular}

As can be seen from the Tab .1. students like English and American literature, especially novels(75\%). Students' desire for British and American literature is very strong(94\%). They are eager to gain knowledge about British and American literature in class in order to improve their literary accomplishment and to expand their international perspective. However, English teaching focus too much on scores for a long time. English teaching is mainly around the center of knowledge and training of the method of solving problem.Ignorance of the student's need of inner emotional, the education is lack of humanistic care. It reflects its obvious utilitarianism. Humanism is ignored, therefore, penetration of British and American literature is very important and have a far-reaching significance. 


\section{THE NECESSITY OF PERMEATION}

\section{A. Cultivate the students' abilities of language learning and using}

Excellent literary works have the following functions: Providing a large number of teaching materials for teachers.Making the class more interesting. Students can read valuable books in a limited time improving the efficiency of learning. Comprehensive ability of English not only include listening, expression, reading, translation and writing which are the five most basic skills of language application, but also include profound cultural accomplishment. All of these can be achieved through simple skill training. Learning a language is not the language itself but the skill of how to use it . Penetration of British and American literature in English teaching can not only make students learn some basic knowledge, such as speech, vocabulary, knowledge of syntax and discourse in the context, but also can help students choose a way of different language expression according to different context or place which can improve their ability of language using.

\section{B. Develop the students' innovative thinking}

It is a good way to develop students' intelligence, promote students to think by allowing the student to think about the complex questions in literary works. But the purpose of reading is not to look for all sorts of authority, unify their understanding of a certain work. Instead, we should encourage students to learn personalized reading and think independently. "Literature itself is a kind of participation, communication and feeling. Literature will not exist without the learner's participation, interpretation and reception". Therefore, any literary text is not qualitative. These unknown, suspense in the literary works require readers to think, image and play. It is the place where students can thnik with imagination and critisim, Students can jon in the reading as readers, take reading as a special experience in which they can feel cannily and construct their own meaning. Thus, reading can become a process where students can think imaginatively and explore initiatively.

\section{Shape students' personality, to cultivate students' ability of analysis}

All the literary works have a common ground, that is to help readers understand their unknown world. British and American literature can help students understand the British and American culture, the Western cultural ideas and value system. British and American literature is a window for students to understand the world and the unknown world. It plays an important role in shaping students' harmonious personality and cultivating students' ability to think and istinguish.Students can also learn from the hero of the literary works to cultivate good ideological and moral characteristics. Putting moralism into the appreciation of literary works is important for students to cultivate correct aesthetic views

\section{THE METHODS OF PERMEATION}

British and American literature can increase students' vocabulary quickly and understand the sentence structure . But how to make English and American Literature penetrated in the course of College English teaching gradually, is necessary for teachers to teach students in accordance with their aptitude. According to the contents of the teaching material, teachers extend the literary works and take different teaching methods.

\section{A. Let students participate in curriculum design actively}

In order to mobilize the students' enthusiasm for English, teachers can arrange the students to play the role of the teachers. Students could introduce a piece of work or writer on the platform, and put forward some requirements. In this case, students no longer accept knowledge passively, and become the dominant in the classroom. They involve in the design of the classroom personally, collect and orginaze the files, write lesson plans, teaching and other aspects of the classroom, so as to avoid the passive acceptance of the inertia of knowledge. The action can promote the classroom atmosphere effectively, on the other hand, it can urge the students to have the purpose and the initiative to dig and analyze the contents of the British and American literature works, so as to deepen the impression and understanding of the work. In the end, it can expand the range for students to obtain knowledge so as to encourage them to use the library and the Internet as a useful supplement to the textbook, improving the ability of independent learning.

\section{B. Recommend literary works to students and ask them to complete the reading response}

Under the influence of the narrow knowledge, many students are at a loss for the choice of the English and American literature works. This needs to recommend the relevant British and American literature works to students according to their actual situation. Because the students' spare time is more fragmented, it needs to highlight the readability of the work itself. Such as "Potter Harry ", "Pride and Prejudice", "the Bible", etc. After completing the reading of the English and American literature works, students completed the reading response, which has a positive guidance and promotion for the understanding of the works. Teachers can better grasp the degree of actual knowledge according to the students' reading response. It is very important for students to improve their reading ability. In addition to, in view of the problem of the assessment of English and American literature in College English teaching, the students can improve their understanding of the content of the works by the way of writing.

\section{Play good English movies}

Now the film also appeared on the screen from the adaptation of literary works, which is more direct to the emergence of the British and American culture. For example, teachers can guide students to watch the movie "seven sins" when referring to the seven major crimes of 
Christianity, in order to promote the implementation of British and American Literature in English teaching.

V.SUMMARY

Academic discussion has reached a consensus and its role is obvious. Reading British and American Literature can improve the students' ability of literature appreciation, so that they cultivate their cross-cultural awareness, which is beneficial to their future work. Throughout the full text, the chapter has done some preliminary research on how to make infiltration of British and American Literature more effective in College English teaching, which is also expected to be further studied.

\section{REFERENCES}

[1] Meng Chaohua,MaSheng cang. British and American Literature Infiltration of English Teaching in Junior School[J]. Overseas English,2014,16:7-9.

[2] Chen Lei. A “Creative Hermeneutics" -based Reform on British and American Literature Classroom Teaching Models[A].Proceedings of the 2015 Northeast Asia International Symposium on Linguistics, Literature and Teaching[C]. Proceedings of the 2015 Northeast Asia International Symposium on Linguistics, Literature and Teaching,2015:6.

[3] Tian Lu. British and American literature and English education[J].Science\&TechnicalInformation,2011,10:169.

[4] Chen Ping. On Learning British and American Literature in English Teaching in High School[J]. Overseas English,2015,04:84-85.

[5] Cao Xiaoming. On Fostering Learner Autonomy in British and American Literature Teaching[D]. Hangzhou Normal University,2007. 